http://dx.doi.org/10.15762/ZH.2015.39

ZOFIA MACIAKOWSKA

(Instytut Historii PAN)

\title{
DWÓR II W STRZYŻY GÓRNEJ I JEGO MIESZKAŃCY W DRUGIEJ POŁOWIE XVIII I NA POCZĄTKU XIX WIEKU
}

Słowa kluczowe: Frantz Gottfried Rottenburg, Brunatti, Gdańsk, Strzyża, dwór, ogród, architektura, mieszczaństwo gdańskie, rezydencje mieszczańskie, rezydencje przedmiejskie mieszczan

W testamencie spisanym w 1796 r. przez małżonków Rottenburg - Frantza Gottfrieda i Annę Marię z domu Brunatti - wśród masy spadkowej wymieniono „das Haus und den Garten in Striess, sowohl mit Alle dazu gehörigen Pertinenz Stücken, als sämtlichen darinnen befindlichen Mobilien"'. Była to nieruchomość, w której posiadanie F.G. Rottenburg wszedł 17 IX 1761 r. $^{2}$ Odwiedzał ją i podziwiał Daniel Chodowiecki w czasie swojego pobytu w Gdańsku w 1773 r. Tak opisał swoje wrażenia: „Das Haus ist groß und sehr kommode gebaut, sein Äußeres ist nicht prunkvoll, es ist wie alle Danziger Häuser, und umgeben von einem schönen, jedoch nicht großen Garten, in dessen Mitte sich ein schöner Springbrunnen befindet, eine in einem großen Bassin liegende Najade hält einen Fisch im Arm, aus dessen Mund das Wasser springt. Um dieses Bassin sind drei Steinfiguren gruppiert, die den Raub der Arethusa darstellen. Sie sind ziemlich gut gemacht von Herrn Meißner, einem Danziger Bildhauer. Dann steigt man fünfzehn Stufen zu einer Terrasse empor und noch einmal soviel zur nächsten, wo sich das Reservoir befindet. Hier liegt ein kleiner Kahn zum Spazierenfahren. Steigt man noch höher, so gelangt man zur Gartenpforte. Dahinter erhebt sich ein ziemlich hoher Berg, den wir fast alle erstiegen, und von dem aus wir fast die ganze Umgegend Danzigs erblickten, die Stadt, Weichselmünde, das Meer mit vielen Schiffen, Wälder, Berge, Ebene, eine reizende Mannigfaltigkeit in der Landschaft"3.

\footnotetext{
${ }^{1}$ Archiwum Państwowe w Gdańsku Oddział w Gdyni (dalej cyt. APG O/Gdynia), sygn. 98/2783, k. $25 \mathrm{v}$.

${ }^{2}$ APG O/Gdynia, sygn. 98/3520, k. 89v. Przywilej z dnia 13 X 1761 r.: Archiwum Państwowe w Gdańsku (dalej cyt. APG), sygn. 940/427, k. 217v; kopia: sygn. 59/4, k. 84r.

${ }^{3}$ Daniel Chodowieckis Künstlerfahrt nach Danzig im Jahre 1773, hrsg. v. Willibald Franke, Leipzig-Berlin [1919], s. 48.
} 
Dwór II w Strzyży był jednym z kilku położonych nad górną częścią potoku o tej samej nazwie, wypływającego niegdyś z kiełpińskiego jeziora, później spośród wzgórz położonych poniżej Kiełpinka4. Ta część obecnego Wrzeszcza z pobliską Oliwą należała do uposażenia oliwskich cystersów zapewne już od końca XII w. ${ }^{5}$ Wieś, w której znajdował się dwór, została założona przez oliwskich cystersów przed 1342 r. Od końca XVI w. opaci oddawali w dzierżawę emfiteutyczną dobra położone w obrębie ich własności ${ }^{6}$. Wiele nadań dotyczyło bogatych mieszczan gdańskich. Pierwszy przywilej związany z nieruchomością, na której znajdował się Dwór II, został wydany 20 II 1646 r. ${ }^{7}$ Nabywano majątki w poszukiwaniu schronienia na upalne letnie miesiące. Zakładane w nich ogrody stawały się przedmiotem podziwu środowiska bogatych mieszczan gdańskich. Znaczenie, jakie im nadawano, widać wyraźnie w obszernych, pełnych zachwytu opisach D. Chodowieckiego, który je zwiedzał podczas swoich konnych wypadów za miasto w 1773 r. ${ }^{8}$

Frantz Gottfried Rottenburg - ostatni długoletni właściciel Dworu II - był bogatym kupcem i armatorem gdańskim. Dnia 6 VII 1756 r. ożenił się z zaledwie siedemnastoletnią Anną Marią Brunatti, córką Francesco di Brunattiego, osiadłego w Gdańsku kupca mediolańskiego ${ }^{9}$. Po ślubie zamieszkał z rodziną w domu przy ul. Szerokiej, na odcinku między ul. Grobla I lub II a ulicą do niej równoległą od strony Motławy ${ }^{10}$. W domu tym przychodziły na świat jego dzieci: Frantz - ochrzczony 8 XI 1757 r., Anna Josephina - 29 V 1759 r., zmarła wkrótce po urodzeniu Lucia Victoria - 28 XII 1760 r., August - 18 VI 1762 r., Ludwig - 2 IX 1764 r., Paul Julius - 1 VII 1766 r., Johanna Magdalena - 21 VII 1767 r., Johann Theodor - 16 IV 1769 r., zmarły w niemowlęctwie Joseph Vincent - 5 IV 1770 r., Juliana Amalia - 22 XI 1771 r. i Friedrich Wilhelm - 4 III 1776 r. $^{11}$

${ }^{4}$ Jako „Secunda Aula” określony został już w 1789 r., APG, sygn. 940/428, k. 39r.

${ }^{5}$ Za taką datacją nadania opowiedzieli się m.in.: Gerard LABUDA, Ze studiów nad najstarszymi dokumentami Pomorza Gdańskiego, Zapiski Towarzystwa Naukowego w Toruniu, t. 18: 1953, s. 122 -128; John Adolf MuHL, Geschichte der Dörfer auf der Danziger Höhe (Quellen und Darstellungen zur Geschichte Westpreußens, Nr. 21), Danzig 1938, s. 112.

${ }^{6} \mathrm{Na}$ temat historii dóbr położonych w Strzyży zob. J.A. MuHL, op.cit., s. 170; Marek KaLIszCZAK, Lucyna SobIEcka, Jerzy SzwED, „Gdańsk-Wrzeszcz. Dokumentacja historyczno-urbanistyczna wykonana na zlecenie Gdańskiego Ośrodka Dokumentacji Zabytków", t. I, Gdańsk 1985 (mps w zbiorach gdańskiego oddziału terenowego Narodowego Instytutu Dziedzictwa).

${ }^{7}$ APG O/Gdynia, sygn. 98/6929, k. 31v. J.A. MuHL (op.cit., s. 170) podaje, że było to odnowienie wcześniejszego przywileju, związane z zakupem dworu przez Christiana Kerschensteina w $1645 \mathrm{r}$.

${ }^{8}$ Zob. np. opis ogrodu w Studzience: Daniel Chodowieckis, s. 104; i Kuźniczkach: ibid., s. 108.

${ }_{9}^{9}$ Archiwum Archidiecezjalne w Gdańsku (dalej cyt. AA Gdańsk), sygn. D 077; Neuer Nekrolog der Deutschen, Jg. 13: 1835, s. 115. Matką była nieznana z nazwiska Euphrosina, zob. AA Gdańsk, Chrzty D 077, 20 IV 1739 r.

${ }^{10}$ AA Gdańsk, Zgony D 118, dla 29 XII 1760 r. i 7 IV 1771 r. Zob. także: Ewa ŁĄCZYŃsKA, Mieszkańcy ul. Szerokiej w świetle spisu z 1770 r., [in:] Studia i materiały do dziejów domu gdańskiego, cz. 2, red. Edmund KızıK, Gdańsk-Warszawa 2011, s. 200. Zapewne po 1779 r. przeniósł się do domu przy Długim Targu 3 (APG, sygn. 98/2783, k. 4r.).

${ }^{11}$ AA Gdańsk, Śluby D 077; Chrzty D 103; Zgony D 118. Trójka młodszych dzieci: Johanna Magdalena, Johann Theodor i Juliana Amalia, została sportretowana przez Chodowieckiego z piastunką w Strzyży, zob. Daniel Chodowieckis, s. 61. 
Krąg towarzyski, w którym się obracał, w jakimś stopniu wyznaczała wyznawana przez małżonków religia: $\mathrm{w}$ odróżnieniu od w większości protestanckiej ludności Gdańska F.G. Rottenburg i jego żona byli katolikami. Więzami rodzinnymi i towarzyskimi związani byli z najznaczniejszymi rodzinami innych gdańskich katolików, a także pomorskiej szlachty i urzędników królewskich ${ }^{12}$. Siostra Frantza Gottfrieda, Adelgunda Rottenburg, była żoną zamożnego kupca i armatora Johanna Philipa Schultza, a po jego śmierci - starosty kościerskiego Konstantego Nowowiejskiego ${ }^{13}$. Siostra żony, Adelgunda Brunatti, była małżonką zamożnego kupca Franza Metzella (także mieszkającego przy ul. Szerokiej) $)^{14}$. Drugim mężem kolejnej siostry - Marii Elisabeth Brunatti - był natomiast Fabritius Schultz ${ }^{15}$. Z rodziny Metzell pochodziła także szwagierka F.G. Rottenburga - Gertrud, żona Johanna Ludwiga Brunatti ${ }^{16}$. Żoną Jacoba Brunatti była natomiast Anna Dorothea Dalmer ${ }^{17}$.

Przedstawiciele tych rodzin oraz rodzin de Matthy i Hannmann bywali dla siebie wzajemnie rodzicami chrzestnymi i świadkami na ślubach. Zdarzało się, że byli rodzicami chrzestnymi urzędników królewskich lub przedstawiciele tych rodzin byli rodzicami chrzestnymi ich dzieci ${ }^{18}$. Między sobą zawierali także związki małżeńskie. Pobrali się m.in.: Johanna Magdalena Rottenburg, córka Frantz Gottfrieda, z Antonem Ignazem de Matthy, synem Antona ${ }^{19}$; Adelgunda Euphrosina Schulz, córka Marii Elisabeth $\mathrm{z}$ domu Brunatti, $\mathrm{z}$ Johannem Frantzem de Matthy ${ }^{20}$.

Niektórzy z tego kręgu towarzyskiego byli właścicielami podmiejskich posiadłości. Do Johanna Philipa Schulza należały: dwór w Młyniskach ${ }^{21}$ oraz pałac i ogród u ujścia kanału Raduni do Motławy, przy ul. Karpiej 26 (pałac ten znany jest pod nazwą Pałacu Nowowiejskiego, od nazwiska drugiego męża Adelgundy Schultz z domu Rottenburg) $)^{22}$.

Być może właśnie fakt posiadania nieruchomości z ogrodami przez członków najbliższej rodziny małżonków Rottenburg zachęcił Frantza Gottfrieda do zaku-

\footnotetext{
${ }^{12} \mathrm{Na}$ powiązania rodzinne gdańskich katolików pochodzących z miejskich elit - funkcjonariuszy pozamiejskich urzędów publicznych oraz zamożnych kupców i armatorów w XVII i XVIII w. - zwrócił już uwagę: Sławomir KoścIELAK, Katolicy w protestanckim Gdańsku od drugiej połowy XVI do końca XVIII wieku, Gdańsk 2012, s. 349-359. Spośród rodzin związanych z osobą F.G. Rottenburga bliżej zajął się przedstawicielami rodzin de Matthy, Metzell, Schultz i Rottenburg.

${ }^{13}$ AA Gdańsk, Śluby D 113, 21 VII 1755 r.; S. KościelaK, op.cit. s. 357; Słownik biograficzny Pomorza Nadwiślańskiego, red. Zbigniew NowaK, t. 4, Gdańsk 1997, s. 177-178.

${ }^{14}$ AD Oliwa, Chrzty D 104, 2 VII 1764 r., 13 II 1767 r.; S. KościelaK, op.cit., s. 358. Zob. także: E. ŁĄCZYŃsKA, op.cit., s. 198. Do spadkobierców kupca Metzel w 1808 r. należała nieruchomość przy ul. Szerokiej 57, zob. APG, sygn. 18/131, s. 55.

${ }^{15}$ AA Gdańsk, Chrzty D 104, 6 IV 1747 r.

${ }^{16}$ Ibid., Chrzty D 077, 1 III 1764 r.

${ }^{17}$ Ibid., Chrzty D 077, 3 VI 1760 r.

${ }^{18}$ Ibid., Chrzty D 104, 21 VIII 1777 r., matką chrzestną Johanna Antona Hannemanna była Teresa Arciszewska.

${ }^{19}$ Ibid., Chrzty D 103, 22 XI 1756 r.

${ }^{20}$ Ibid., Chrzty D 104, 11 XI $1771 \mathrm{r}$.

${ }^{21}$ APG, sygn. 940/428, k. 35v.

${ }^{22}$ Ibid., sygn. 300,32/19, s. 220, 222.
} 
pu emfiteutycznego gospodarstwa w Strzyży Górnej w 1761 r., a następnie pałacu Jerzego Wandalina Mniszcha położonego przy Długich Ogrodach na przedmieściach Gdańska w 1786 r. ${ }^{23}$ Nie jest jednak wykluczone, że chciał w ten sposób ugruntować swoją pozycję jako osoby godnej starania się o przynależność do stanu szlacheckiego. Te plany wpływały też zapewne na dobór osób, między którymi się obracał. Nobilitację otrzymał ostatecznie na kilka lat przed śmiercią - w 1790 i $1793 \mathrm{r}^{24}$

Synom rodzin skoligaconych z Rottenburgami nieobce były sprawy Polski: kapitanem wojsk polskich był Joseph Brunatti, brat pani Rottenburg; Ludwik Metzell był oficerem artylerzystą $\mathrm{w}$ wojsku polskim, uhonorowanym za odwagę podczas bitwy pod Zieleńcami w 1792 r. orderem Virtuti Militari'25; syn F.G. Rottenburga, także Frantz, początkowo służył w armii francuskiej jako podporucznik (1782) (second lieutenant), później w randze porucznika (1785), a następnie, po powrocie do Polski w 1791 r. dowodził batalionem piechoty w powstaniu kościuszkowskim i został ranny w czasie bitwy o Pragę w $1794 \mathrm{r}^{26} \mathrm{D}$. Chodowiecki wspominał, że poczuł się urażony formą, w jakiej o królu pruskim w domu i w obecności Rottenburga mówił jego szwagier pan Brunatti (zapewne Joseph) ${ }^{27}$.

Dwór w Strzyży, opisany przez Chodowieckiego w 1773 r., umożliwiał godne przyjmowanie licznych gości. Zarówno budynek dworu, jak i ogród zostały zaplanowane zgodnie z ówcześnie panującą modą. W odróżnieniu od ogrodu, który spotkał się z podziwem artysty, dom nie wzbudził jego większego zainteresowania ${ }^{28}$. Stworzenie nowej formy całego założenia wymagało całkowitej zmiany wcześniejszego. Zabudowania zakupione w $1761 \mathrm{r}$. przez Rottenburga były bowiem stosunkowo skromne. Jak wynika z kontraktu z 1659 r., do dworu należały zabudowania gospodarcze, ogród i pola uprawne o powierzchni 2 łanów ${ }^{29}$. Na rycinie Mattheusa Deischa $\mathrm{z}$ albumu widoków Gdańska wykonanych w latach 1761-1765 na działce

\footnotetext{
${ }^{23} \mathrm{Na}$ jego aspiracje wskazuje także fakt zakupu nieruchomości od polskich magnatów; także dom przy ul. Długi Targ 3 Frantz Gottfried zakupił od przedstawiciela tego stanu, hrabiego Ignacego Przebendowskiego w 1779 r. Na temat historii pałacu Mniszchów zob. w: Zofia MaciakowsKa, Pałac Jerzego Wandalina Mniszcha w Gdańsku u schyłku XVIII w., [in:] Studia i materiały do dziejów domu gdańskiego, cz. 3, red. Edmund Kızıк (w druku).

${ }^{24}$ Album armorum nobilium Regni Poloniae XV-XVIII w., oprac. Barbara Trelińska, Lublin 2001, s. 779, nr 2445; Materiały genealogiczne, nobilitacje, indygenaty w zbiorach AGAD w Warszawie, oprac. Anna Wajs, Warszawa 2001, s. 103. Dziękuję Pani dr Ewie Bojaruniec za wskazanie tych informacji.

${ }^{25}$ S. Kościelak, op.cit., s. 359; Mirosław Gliński, Jerzy Kukliński, Kronika Gdańska, t. 1: 997-1945, Gdańsk 1997, s. 118.

${ }^{26}$ http://www.biographi.ca/en/bio.php?Biold=37228, dostęp z 3 V 2015 r.

${ }^{27}$ „Wir plauderten, doch wurde Unterhaltung durch Herrn Brunati fast etwas ungemütlich, weil er sich über den König in einer Weise aussprach, auf die einzugehen mir nicht beliebte" (Daniel Chodowieckis, s. 48).

${ }^{28}$ Jako jedyny interesujący nowy budynek w Gdańsku Chodowiecki wskazał pałac Theodosiusa Christiana Frantziusa przy ul. Słodowników (Daniel Chodowieckis, s. 428).

${ }^{29}$ M. Kaliszczak, K. Sobiecka, J. Szwed, op.cit., s. 164. Pewne wskazówki na temat wcześniejszej wielkości nieruchomości zawiera przywilej z 14 II 1612 r., zob. APG, sygn. 59/4, nr 340a, 340b.
} 


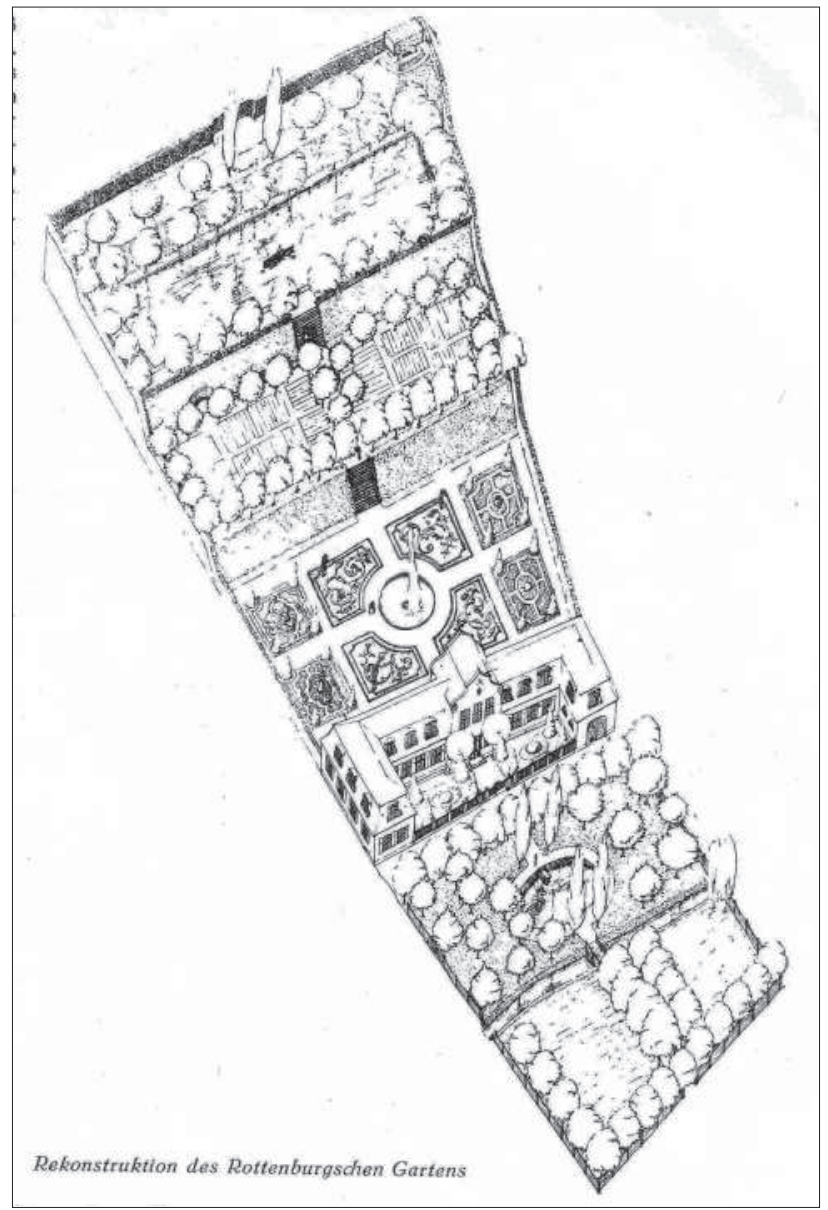

1. Rekonstrukcja układu i formy Dworu II w Strzyży Górnej (według: Hans ReICHow, Der bürgerliche Gartenkunst, Berlin 1927, s. 27)

położonej na skłonie wzgórza widoczne są ustawione szczytem do drogi szkieletowe budynki ${ }^{30}$. Być może wszystkie lub tylko lewy skrajny znajdowały się na późniejszej działce dworskiej. Rottenburg wzniósł w ich miejscu nowy budynek i od nowa zaaranżował ogród ${ }^{31}$. I choć dużo o dworze i ogrodzie opowiadano i pisano, w rzeczywistości mało było o nich wiadomo. Na podstawie analizy opisu D. Chodowieckiego i analizy widocznych jeszcze w latach trzydziestych XX w. pozostałości obiektu Hans Reichow wykonał rysunek odtwarzający jego stan w końcu XVIII w.3. (il. 1).

${ }^{30}$ Mattheus DeIsch, 50 Prospekte von Danzig, Danzig 1765, il. 46.

${ }^{31} \mathrm{~W}$ opisie D. Chodowieckiego brakuje jakiejkolwiek wzmianki na temat niedawnego założenia oglądanego przez niego ogrodu. W przywileju dla Rottenburga mowa o zabudowaniach, ogrodach i stawach, zob. APG, sygn. 940/427, k. 217v.

${ }^{32}$ Hans Reichow, Der bürgerliche Gartenkunst, Berlin 1927, s. 27. Pewne szczegóły rysunku rekonstrukcyjnego budynku wskazują, że badacz mógł znać opis inwentaryzacyjny nieruchomości z wyceny w 1814 r., por. APG O/Gdynia, sygn. 98/6929, k. 21r-22v. 
Pokazano na nim budynek dworu jako parterowy $\mathrm{z}$ wysokim dachem mansardowym, z ryzalitem środkowym o rokokowej formie, z którego wychodziły w kierunku podjazdu dwa krótkie skrzydła. Między drogą prowadzącą ze Strzyży Dolnej do Brętowa a dworem miał się znajdować według H. Reichowa ogrodzony park z sadzawką w części położonej na południe od potoku. Płot miał także wydzielać przydworski dziedziniec. Za budynkiem rozciągał się na zboczu tarasowo uformowany ogród.

Sposób ukształtowania części frontowej założenia nie odpowiada opisowi zawartemu w wycenie nieruchomości z $1814 \mathrm{r}$. wykonanej przez gdańskiego budowniczego miejskiego Carla Samuela Helda ${ }^{33}$ (aneks źródłowy). Jest w nim mowa o stawie, a nie sadzawce, a ogrodzenie miało wydzielać szeroko rozumiany dziedziniec od drogi. Z opisu można wnioskować, że dwór usytuowany był w pewnym oddaleniu od drogi prowadzącej przez wieś Strzyżza ${ }^{34}$. Między drogą a dworem płynął potok o tej samej nazwie, na którym w obrębie nieruchomości należącej do Rottenburga utworzono staw otoczony drzewami. Położony od strony drogi dziedziniec obwiedziony był ogrodzeniem o murowanych słupkach ${ }^{35}$. W tylnej części parceli, na północnym stoku wyniesienia - między zabudowaniami a drogą prowadzącą z Wrzeszcza do Brętowa - znajdował się niewielki ogród, otoczony płotem, o długości zaledwie 320 stóp $(91,8 \mathrm{~m})$ i szerokości odpowiadającej wielkości budynku ${ }^{36}$. Miał układ tarasowy. Pierwszy poziom położony przy samym budynku zajmował ogród francuski z fontanną. Na drugim, wyniesionym w stosunku do pierwszego o 15 stopni, znajdował się sad. Na trzecim, podobnie wyniesionym - staw, po którym pływano łodzią i którego woda zasilała fontannę znajdującą się na najniższym poziomie ${ }^{37}$. Pływały w nim karpie, których karmienie było towarzyską rozrywką. Według $\mathrm{H}$. Reichowa na kolejnym poziomie miała się także znajdować altana umieszczona na kopcu widokowym, z którego można było podziwiać rozległą panoramę z Zatoką Gdańską ${ }^{38}$. D. Chodowiecki o nim jednak nie wspominał. Krajobraz był wówczas podziwiany ze szczytu wzgórza, na którego zboczu znajdował się ogród. Na wschód od założenia znajdowały się inne zabudowania gospodarcze $^{39}$.

${ }^{33}$ APG O/Gdynia, sygn. 98/6929, k. 21r-22v.

${ }^{34}$ Usytuowanie dworu utrwalone zostało na planach z pierwszych lat XIX w.: APG, sygn. 300 MP/3; Biblioteka Gdańska PAN (dalej cyt. BG PAN), sygn. C I-76; I-b; C I-77.

${ }^{35}$ Tak zapewne należy rozumieć użyte w wycenie sformułowanie: „die Mauer von der Einfassung des Hofes".

${ }^{36}$ Zobacz aneks źródłowy.

${ }^{37}$ Daniel Chodowieckis, s. 54.

${ }^{38}$ H. Reichow, op.cit., s. 29; Walther Domansky, „Danziger Allerlei”. Gesammelte Aufsätze, Danzig 1903, s. 13.

${ }^{39}$ O przynależności tego terenu do Dworu II świadczy plan sytuacyjny z 1917 r., na którym znalazły się adnotacje o właścicielach działek będących przedmiotem pomiarów. Zarówno działka z dworem, jak i działki położone od niej na północ i wschód należały do tego samego właściciela, zob. APG O/Gdynia, sygn. 98/6927, k. 176r. Zabudowania gospodarcze na wschód od dworu widoczne są także na rysunku z 1886 r. (zob. przyp. 41). 


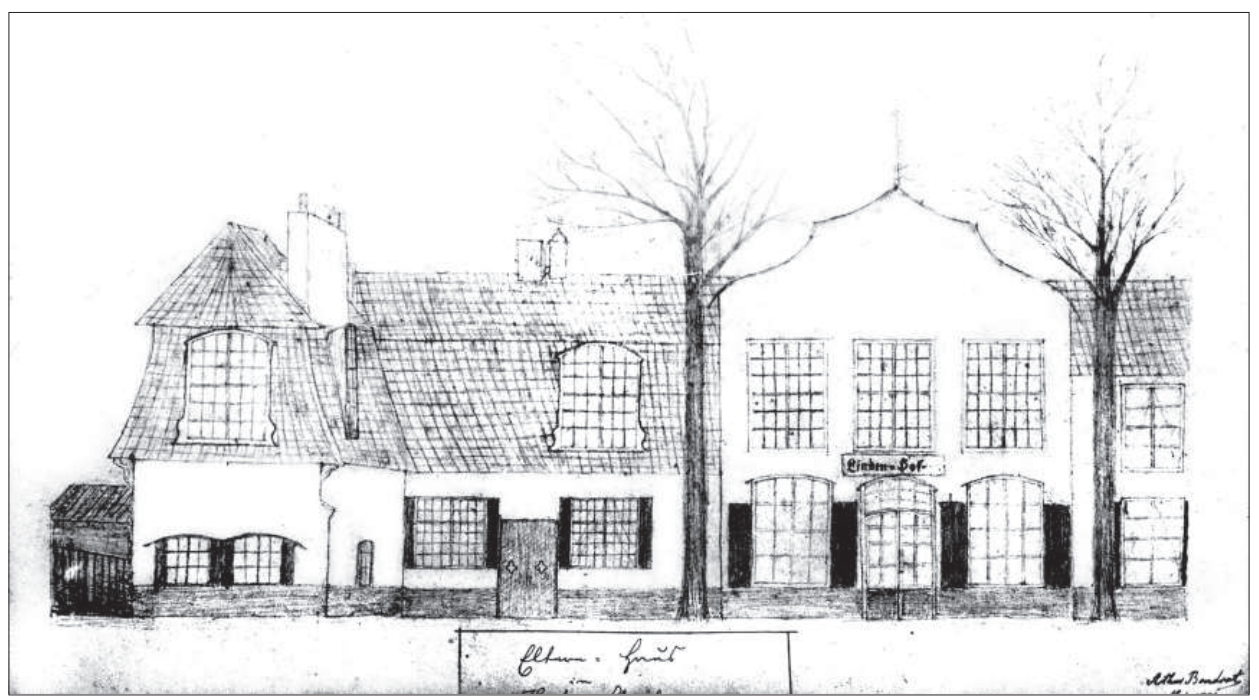

2. Widok Dworu II w Strzyży Górnej od strony północnej na rysunku Arthura Bendrata z 1882 r. (Biblioteka Gdańska PAN, Zbiory fotograficzne, sygn. III/803)

W 1814 r. dwór określony został jako „das herschaftliche Gartenhaus”, co zapewne miało podkreślić zarówno rozmach założenia, jak też jego integralne powiązanie $\mathrm{z}$ ogrodem. Budynek miał bardzo znaczną długość - 159 stóp (45,6 m) i zapewne około $11,5 \mathrm{~m}$ szerokości ${ }^{40}$. Wychodziły $\mathrm{z}$ niego $\mathrm{w}$ kierunku podjazdu dwa skrzydła boczne - jedno o długości $31^{1 / 2}(9 \mathrm{~m})$ i szerokości $21^{1 / 2}$ stopy $(6,2 \mathrm{~m})$ i drugie odpowiednio: $20 \times 24$ stopy $(5,74 \times 6,9 \mathrm{~m})$. Miał sklepione piwnice, był parterowy, nakryty wysokim dachem mansardowym ${ }^{41}$. W partii centralnej był dwukondygnacyjny. Jak wynika $\mathrm{z}$ opisu formy szczytu tej części budynku przez D. Chodowieckiego, była ona zbliżona do typowej dla gdańskich kamienic tego czasu. Na dziecinnym rysunku z 1882 r., przedstawiającym widok dworu od strony podjazdu, pokazany został szczyt o przełamanej falistej linii spływów $w^{42}$. Pod gzymsem miała się znajdować wykonana w stiuku (tynku?) litera $\mathrm{R}^{43}$. Partia środkowa, być może akcentowana niewielkim ryzalitem, była trzyosiowa, partie boczne miały po 6 osi okiennych. W kondygnacji poddasza znajdowało się o dwa okna mniej.

${ }^{40} \mathrm{~W}$ aktach gruntowych (APG O/Gdynia, sygn. 98/6928, k. 67r) znajduje się plan sytuacyjny działki z 1938 r. wykonany w skali 1 : 1000. Pokazany na planie budynek, oznaczony numerem 10, oddalony jest od południowej granicy działki o około $92 \mathrm{~m}$, więc na tę samą odległość co kiedyś budynek dworu. Można więc przypuszczać, że do jego wzniesienia wykorzystano fragmenty fundamentów lub nawet piwnic dawnego obiektu. Pozwala to określić jego szerokość na około 11,5 m.

${ }^{41}$ Trudno stwierdzić, czy opis ten znany był H. Reichowowi. Narysowany przez niego budynek jest zbliżony do tego z wyceny C.S. Helda.

${ }^{42}$ Autorem rysunku był Arthur Bendrat, urodzony 22 IV 1872 r. Był on wnukiem ówczesnej właścicielki dworu, Christine Louise Domansky, z domu Heyden, wdowy po Ernscie Jacobie. Christine Louise była matką pastora Walthera Domanskyego, autora licznych opowiadań i prac na temat historii Gdańska (APG O/Gdynia, sygn. 98/6929, k. 265r-266r, 277r).

${ }^{43}$ W. Domansky, op.cit., s. 11. 


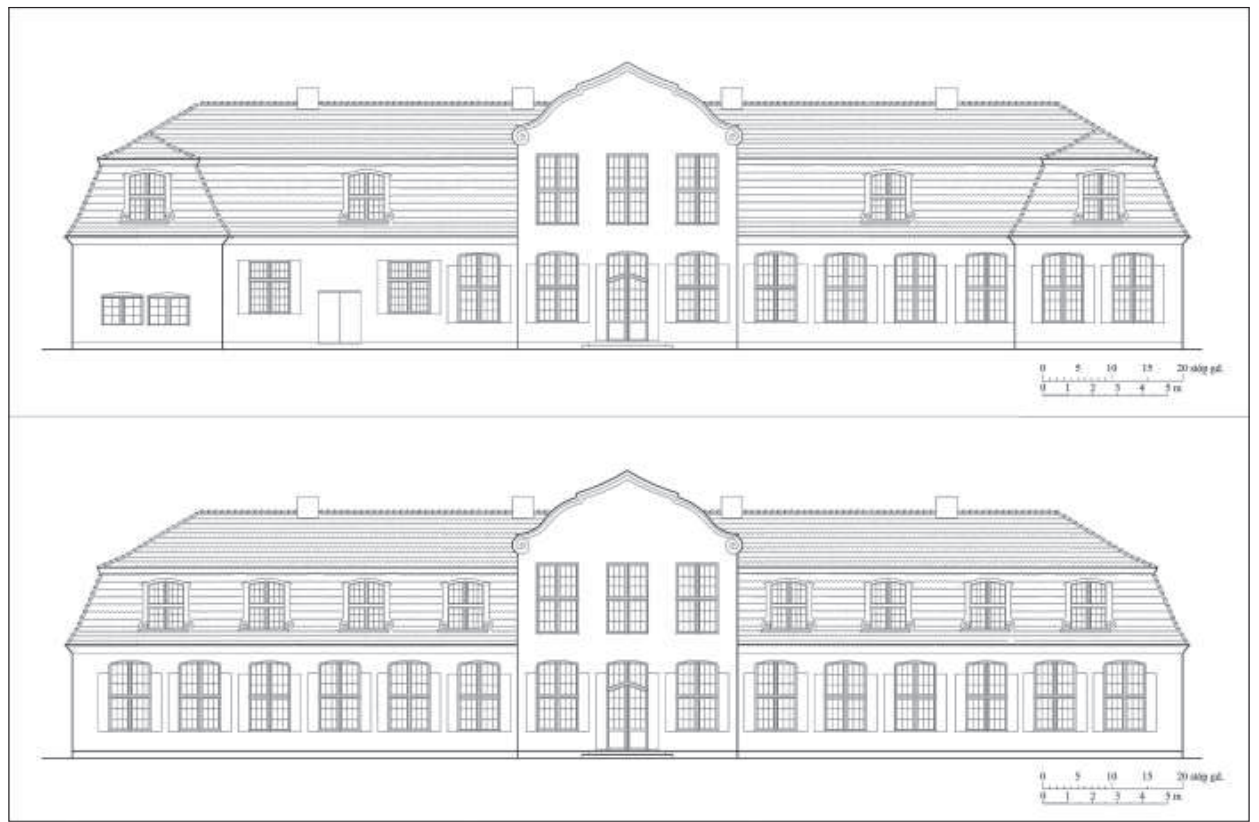

3. Rekonstrukcja elewacji Dworu II w Strzyży Górnej na podstawie analizy zapisów wyceny nieruchomości z 1814 r. (opracowanie autorki)

Można przypuszczać, że skrzydła boczne były przykryte podobnym mansardowym dachem, tak jak pokazał to autor rysunku z $1886 \mathrm{r}^{44}$ Na podstawie informacji zawartych w opisie wyceny z $1814 \mathrm{r}$. oraz analizy rysunku podjęto próbę odtworzenia elewacji dworu - od strony podjazdu (północ) i ogrodu (południe) (il. 2, 3).

$\mathrm{W}$ odniesieniu do tych samych danych opracowano hipotetyczne rozplanowanie wnętrz ${ }^{45}$. Do budynku wchodziło się przez osiowo umieszczone drzwi. Za nimi znajdowała się biegnąca na przestrzał sień. Ściany sieni pokryte były papierowymi tapetami. Podłogi wyłożone były deskami, a sufit pokryty sztablaturą. Podobne było wykończenie wszystkich pomieszczeń dworu. Od strony ogrodu, po prawej stronie znajdował się ogrzewany pokój - zapewne bawialnia - a za nim kolejny, niewielki. Przechodziło się z niego do sali jadalnej zajmującej nie tylko szczytową partię budynku, lecz także skrzydło boczne ${ }^{46}$. Wszystkie okna przyziemia w kor-

${ }^{44}$ BG PAN, Zbiory fotograficzne, sygn. III/803.

${ }^{45}$ Podczas wykonywania planu przyziemia i poddasza starano się nadać uzyskanym ze źródeł informacjom formę przestrzenną zgodną ze sztuką budowlaną i zasadami rozplanowania wnętrz w obiektach o zbliżonym charakterze. Na podstawie opisu nie można było w sposób jednoznaczny ustalić układu pomieszczeń ani w części wschodniej budynku od strony podwórza, ani w przylegającym do niej skrzydle. Przedstawiony na rysunkach układ wydaje się najbardziej prawdopodobny. Te same trudności występowały w odniesieniu do pomieszczeń poddasza.

${ }^{46} \mathrm{~W}$ swojej rysunkowej rekonstrukcji $\mathrm{H}$. Reichow przyjął, że skrzydło mieszczące jadalnię znajdowało się po wschodniej stronie budynku, a stajnie i wozownie w zachodniej. Nie wydaje się to właściwe. W tekście wyceny z 1814 r. wyraźnie napisano, że jadalnia znajdowała się w części położonej na prawo od sieni, patrząc w stronę ogrodu. Potwierdza to także analiza rysunku A. Bendrata, 
pusie głównym były czteroskrzydłowe ${ }^{47}$. W trakcie od strony podjazdu znajdowała się kuchnia $\mathrm{z}$ belkowym stropem oraz ogrzewana izba o ścianach wyklejanych papierową tapetą. Trudno stwierdzić, czy mogła być ona dostępna $\mathrm{z}$ holu i wykorzystywana przez rodzinę właścicieli lub gości, czy też tylko od strony kuchni i stąd przeznaczona dla kucharki i podkuchennych.

W części wschodniej od strony ogrodu obok sieni mieściła się kolejna bawialnia z marmurowym kominkiem, a za nią oranżeria ${ }^{48}$. W trakcie tylnym natomiast izba, a za nią mieszkanie ogrodnika składające się z izby i kuchni. W pomieszczeniach reprezentacyjnych od strony ogrodu na ścianach znajdowały się tapety, drewniane boazerie wymienione są tylko we wschodniej bawialni i jadalni. Najprawdopodobniej w pozostałych pomieszczeniach też się początkowo znajdowały, ale zostały zdemontowane i spalone podczas oblężenia Gdańska w 1813 r. Skrzydło boczne znajdujące się z tej strony zawierało ustęp, boksy dla koni i wozownię.

Nie wiadomo, gdzie znajdowały się schody prowadzące na piętro. Zazwyczaj umieszczano je w sąsiedztwie głównego wejścia, w sieni. Zapewne wychodziły na piętrze na korytarz biegnący wzdłuż korpusu. Centralne miejsce zajmowała tu wysoka sala z trzema oknami wychodzącymi na ogród, do której wchodziło się dwuskrzydłowymi drzwiami. Po jej stronie wschodniej znajdował się obszerny gabinet, a za nim trzy kolejne, wąskie. Po drugiej stronie znajdował się szereg dalszych izb (il. 4).

Niektóre z wymienionych pomieszczeń odwiedzane były przez D. Chodowieckiego. Niestety, nie opisał ich. Jako godne zainteresowania uznał jedynie kilka obrazów wiszących na ścianach pomieszczeń przyziemia oraz 12 francuskich Häfen (grafik autorstwa Callo) znajdujących się w sali na piętrze ${ }^{49}$.

Frantz Gottfried Rottenburg korzystał z rodziną ze swojej wiejskiej posiadłości do 1799 r. Zmarł 9 marca tego roku, jego żona przeżyła go zaledwie o pół roku ${ }^{50}$. W ramach rozliczeń spadkowych po jej śmierci dwór w Strzyży, podobnie jak dom

na którym zaznaczono niewielkie okna w skrzydle wschodnim, odpowiednie dla stajni, a nie jadalni. Stajnia i wozownia znajdowały się więc od strony gospodarczej części nieruchomości i z tej strony najwyraźniej znajdował się do nich dojazd. Także na planie z 1807 r. (APG, sygn. 300 MP/3) pokazano, że dłuższe skrzydło (zawierające pomieszczenia gospodarcze) znajdowało się po tej stronie dworu.

${ }^{47}$ Ich nadproże mogło być poprowadzone płasko (jak np. w Dworze V przy Polankach) lub prawie płaskim łukiem (jak w Dworze II, tamże).

${ }^{48}$ Jako marmurowy opisał go: W. Domansky, op.cit., s. 12.

${ }^{49}$ Daniel Chodowieckis, s. 48: „Auch sämtliche Zimmer besichtigten wir, wo wir jedoch in bezug auf Malerei nichts Bemerkenswertes fanden, außer zwei Gemälden, davon eine Wildbret und Gefügel und das andere, Apolllo und Marsyas, Halbfiguren, von einem italienischen Meister dargestellt, welches als Gegenstück einen Heiligen Sebastian haben sollte, den wir jedoch nich sahen. [...] In einem oberen Saale hat er zwölf der französischen Häfen (Radierungen von Callo)".

${ }^{50}$ Żona F.G. Rottenburga zmarła 23 X 1799 r. Oboje zostali pochowani w grobowcu rodzinnym na cmentarzu kościoła Zbawiciela. Tu spoczęli także trzej ich synowie: Johan Theodor, zmarły 2 IV 1813 r.; Paul Julius, zmarły 8 XII 1817 r.; Friedrich Wilhelm, zmarły 15 VIII 1849 r.; dwie małoletnie córki Paula Juliusa i wnuk - Anton Franz Matthy, zmarły 19 VII 1866 r., syn ich córki, Johanny Magdaleny, żony Ignatza Antona Matthy'ego. 


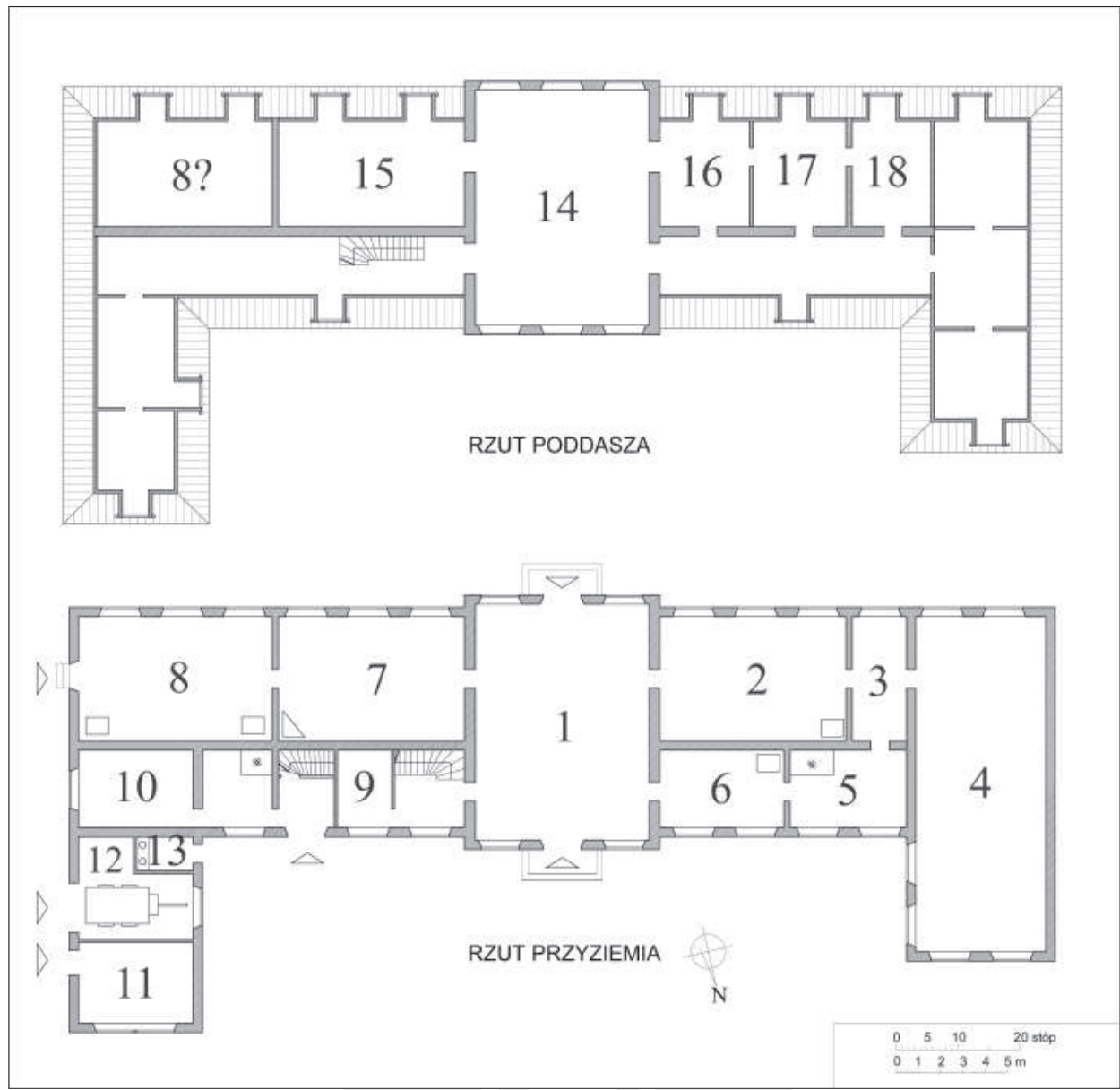

4. Rekonstrukcja układu wnętrz Dworu II w Strzyży Górnej na podstawie analizy zapisów wyceny nieruchomości z 1814 r. (opracowanie autorki):

1 - sień; 2- bawialnia, 3 - kredens; 4 - jadalnia; 5 - kuchnia; 6 - izba; 7 - bawialnia; 8 - oranżeria; 9 - izba; 10 - mieszkanie ogrodnika; 11 - stajnie; 12 - powozownia; 13 - ustępy; 14 - sala; 15-18 - gabinety.

przy Długim Targu 3, stanął na licytacji. W dniu 22 V 1800 r. dwór zakupił za 7200 talarów Paul Schnaase ${ }^{51}$. Jednak niecały rok później odkupił go Paul Julius Rottenburg, jeden z synów Frantza Gottfrieda. Był on, podobnie jak ojciec, kupcem; jego żoną była Carolina Sabina $\mathrm{z}$ domu Dubois ${ }^{52}$. Trudno ocenić, czy to za jego czasów dokonano pewnych zmian w ogrodzie, czy też były jeszcze dziełem jego ojca. Zlikwidowano centralnie biegnącą ścieżkę ze schodami, przecinającą wzdłuż cały ogród. W jej miejsce wprowadzono ścieżkę wzdłuż wschodniej granicy zało-

${ }^{51}$ APG O/Gdynia, sygn. 98/3520, k. 89v.

${ }^{52}$ Ibid. Transakcja zawarta została 10 III 1801 r. Paul Julius nabył nieruchomość za 6000 talarów. 
żenia, prowadzącą na najwyższy poziom, na taras z kopcem widokowym i altaną. $\mathrm{W}$ miejscu schodów między ogrodem francuskim a pierwszym tarasem zbudowano kamienną grotę z kaskadą wypływającą $\mathrm{z}$ tylnej ściany groty $\mathrm{z}$ wylewki $\mathrm{w}$ formie zwierzęcej paszczy ${ }^{53}$. Były to przekształcenia nadające barokowemu ogrodowi sentymentalny charakter, modny w końcu XVIII w.

Paul Julius nie osiągnął sukcesu w prowadzeniu interesów, co doprowadziło go do bankructwa. W ramach regulacji zobowiązań finansowych względem wierzycieli - jednym z nich była jego siostra Johanna Magdalena Matthy z domu Rottenburg - nieruchomość została wystawiona na licytację w dniu 3 II 1816 r. i zakupiona za 1620 talarów przez Antona Franza Matthy, jej syna ${ }^{54}$. Niska cena wynikała ze stanu, w jakim znajdowały się zabudowania, w znacznym stopniu zdewastowane w czasie oblężenia Gdańska w 1813 r. ${ }^{55}$

Wkrótce po zakupie nieruchomość ponownie zmieniła właściciela. Dnia 7 IX 1818 r. nabył ją królewsko-pruski radca rządowy Carl Gottlieb Hartmann. W ten sposób zakończył się okres prawie sześćdziesięcioletniego gospodarowania rodziny Rottenburgów w Strzyży. Od tego czasu dwór przechodził różne koleje losu, uległ też ponownej dewastacji wynikającej z zaniedbań właścicieli i użytkowników (do $1870 \mathrm{r}^{56}$ ) i wielokrotnie zmieniał właściciela. Opis jego wnętrz i ogrodu z lat siedemdziesiątych XIX w. zawdzięczamy Waltherowi Domańskiemu. Dwór nosił wówczas nazwę „Lindenhof”. W tym czasie, mimo częściowej przebudowy domu (nadbudowa, likwidacja zachodniego skrzydła) i przekształceń ogrodu, istniały jeszcze ślady dawnej świetności tego założenia ${ }^{57}$. Nadal podziw wzbudzała obszerna sień, na której ścianach wyeksponowane były egzotyczne osobliwości, takie jak indiańskie włócznie i wiosła, oraz sala ponad nią, zaadaptowana na trzy pomieszczenia, z której widać było morze. Podzielone na dwie kondygnacje przesklepione, sąsiadujące ze sobą pomieszczenia znajdujące się w kondygnacji przyziemia (oranżeria?) przypominały podobno kaplicę.

Wkrótce pojawiły się dalsze zmiany zwiastujące ostateczną zagładę zespołu dworskiego. Najpierw dokonano podziału nieruchomości w związku z wydzieleniem nowej ulicy - Obywatelskiej - między ul. Słowackiego a Partyzantów w $1885 \mathrm{r}^{58}$ Wkrótce potem dom rozebrano. Na dawnej działce dworu powstały trzy nowe obiekty ${ }^{59}$. W 1939 r. poszerzono pas drogowy ul. Partyzantów, zajmując

${ }^{53}$ W. Domansky, op.cit., s. 12-13.

${ }^{54}$ Johanna Magdalena pożyczyła bratu 1000 dukatów (APG O/Gdynia, sygn. 98/6929, k. 26r-27 r). Na temat licytacji zob. ibid., sygn. 98/3520, k. 89v.

${ }^{55}$ Ibid.

${ }^{56}$ Wskazuje na to spadek wartości nieruchomości z 11200 na 500 talarów, zob. ibid., sygn. 98/3520, k. 90v.

${ }^{57}$ Utrzymany był jednak staw na drugim tarasie, a na pierwszym tarasowym wyniesieniu - tak jak za czasów F.G. Rottenburga - nadal rosły drzewa owocowe oraz trzy orzechy. Sadzawka fontanny została zamieniona w klomb kwiatowy, zob. W. Domansky, op.cit., s. 12.

${ }^{58}$ APG O/Gdynia, sygn. 98/6927, k. 268r.

${ }^{59} \mathrm{Z}$ powodu niezachowania się odpowiednich akt Policji Budowlanej nie udało się ustalić, w którym roku dwór ostatecznie rozebrano. 
na ten cel fragment najwyższego tarasu ${ }^{60}$. Obecnie trudno w tym miejscu doszukać się jakichkolwiek śladów dawnej posiadłości Rottenburgów.

${ }^{60}$ APG O/Gdynia, sygn. 98/6927, k. 67r-68r.

\title{
ANEKS ŹRÓDŁOWY
}

Opis Dworu II w Strzyży Górnej autorstwa Carla Samuela Helda, gdańskiego budowniczego miejskiego, $z 1814 \mathrm{r}$.

Kopia: Archiwum Państwowe w Gdańsku Oddział w Gdyni, sygn. 98/6929, k. 21 r$-22 v$.

\begin{abstract}
Abschätzung
Des dem Negotianten Herrn Rothenburg zu Hochstrieß zugehörigen Grundstücks, welches in einem herrschaftlichen Gartenhause mit einem Lustgarten und in 2 Teichen bestehet.

Das herrschaftliche Gartenhaus ist 159. Fuß lang, - Fuß tief ${ }^{1}$, und mit 2. Seiten Flügel verbunden, von welchem einer derselben $21 \frac{1}{2}$ Fuß breit, $31 \frac{112}{2}$ Fuß lang, der andere aber 24. Fuß breit und 20. Fuß lang ist: außer einem gewölbten Keller ist dieses Gebäude nebst den Seitenflügeln mit Inbegriff der Dach Etage 2. Etagen hoch erbaut.

In der Etage parterre von 14. Fuß Höhe welche durchgängig mit vierflüglichten Sproßenfenstern als auch mit Gypsdeken und Diehlenfluhren angelegt ist, ist die Entrée von 2. Fach Fenster mit Papier tapeziert, - rechts nach der Gartenseite ist ein heitzbares und tapeziertes Zimmer von 3. Fach Fenstern nebst einem kleinern dito von einem Fenster und mit einem darneben belegenen Speisesaal aptirt, welcher im Seitenflügel durchgängig und mit Lamberie von Holz versehen ist. In derselben Hälfte des Hauptgebäudes liegt nach hinten eine Küche von 2 Fenster mit einer Balkendeke nebst einen tapezirten und heitzbaren Stube von 2. Fach Fenstern.

Zur linken Hand der Entrée nach dem Garten hin ist wiederum ein tapezirtes Zimmer von 3. Fenstern mit einer Kaminheitzung und mit einer Lamberie von Holz, mit einer dahinter folgenden gleichgroßen Gewächsstube, von 2 ordinairen Oefen belegen, hingegen nach hinten ist eine Kammer mit 1. Fenster nebst einer Gärtner Wohnung von einer Stube und Küche, und im Flügel die Pferde-Stallung, Wagen Remise und ein Apartement aptirt.
\end{abstract}

${ }^{1}$ Brak liczby, w tym miejscu myślnik. 
In der Dach Etage, welche außer der mittleren Partie 101/4 Fuß hoch ist, ist ein Saal von 3. vierflüglichten Sproßenfenstern, mit Flügelthüren Lamberie von Holz und mit Gypsdeke, imgleichen ein Kabinet von 2 Fenster nebst 3. andern von 1. Fenster mit mehreren diversen Kammern befindlich.

Durch die Zeit des Krieges hat dieses Gebäude, in Betreff der Fußboden und Tapeten als auch in Ansehung der Fenster etwas gelitten, imgleichen ist die Mauer von der Einfaßung des Hofes destruirt und die Garten Zäune fehlen.

Der zwischen dem Fahrwege und dem Mühlen-Fluß belegene und hier zugehörige Platz auf welchem sich ein Teich befindet ist mit mehreren Bäumen besetzt. Der Garten ist 320 Fuß lang bis an den brentauschen Weg gemessen, und mit einem nach oben belegenen Teich, als auch mit einer defecten massiven Grotte und Fontaine decorirt, so wie mit mehreren Obstbäumen besetzt.

Dieses Grundstück behauptet wegen der Nähe der Stadt, seinen eigenthümlichen Vorzuge, und mit Hinsicht auf dieselben ist der jetzige Werth desselben $11000 \mathrm{fl}$ DC schreibe Elftausend Gulden Danziger Courant als welches ich hiemit pflichtmäßig attestire

Danzig d. 14. May 1814

Held

dr Zofia Maciakowska

Instytut Historii PAN

e-mail:zofiam@poczta.onet.eu

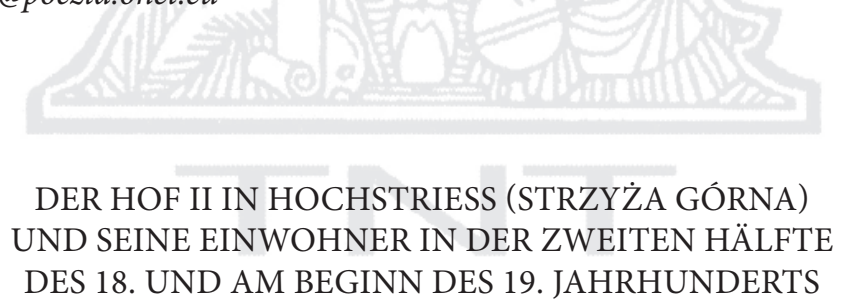

Zusammenfassung

Schlüsselwörter: Frantz Gottfried Rottenburg, Brunatti, Danzig, Hochstrieß, Hof, Garten, Architektur, Danziger Bürgertum, Bürgerresidenzen, Vorstadtresidenzen der Bürger

In dem Artikel habe ich den Versuch unternommen, den Plan und die Form des Hofes II in Hochstrieß zu rekonstruieren und die Person seines damaligen Eigentümers vorzustellen. Dieser Hof war einer von mehreren, die am oberen Abschnitt eines Bachs des gleichen Namens gelegen waren. Am 17. September 1761 gelangte der wohlhabende Danziger Kaufmann Frantz Gottfried Rottenburg in seinen Besitz. Er war ein Katholik, der durch verwandtschaftliche und gesellschaftliche Beziehungen mit den begüterten Familien anderer Danziger Katholiken verbunden war. Zu diesen gehörten Vertreter der Familien Brunatti (aus dieser Familie stammte seine Frau), de Matthy, Metzell und Schultz. Einige 
Zeit nach dem Kauf wurde der Hof in Hochstrieß völlig umgebaut oder ganz neu errichtet. Sowohl das Haus wie der Garten wurden nach der damals herrschenden Mode geplant. Man nutzte die Vorteile seiner Lage aus. Hinter dem Haus, am Abhang eines Hügels, befand sich ein terrassenförmig gestalteter Garten, der von den zahlreichen Besuchern des Anwesens bewundert wurde. Auf dieser Seite befanden sich die repräsentativen Salons des Hofes, in denen die Gäste empfangen wurden, sowie eine Orangerie. Aus dem Salon im oberen Stockwerk hatte man auch einen weiten Blick auf die Seeauen und auf das Meer.

\author{
DWÓR II [MANOR HOUSE II] IN STRZYŻA GÓRNA \\ AND ITS INHABITANTS IN THE SECOND HALF OF THE $18^{\text {TH }}$ CENTURY \\ AND AT THE BEGINNING OF THE $19^{\text {TH }}$ CENTURY
}

\title{
Summary
}

Key words: Frantz Gottfried Rottenburg, Brunattis, Gdansk, Strzyża, manor house, garden, architecture, the Gdansk burghers, residences of burghers, suburban residences of burghers

In this article I attempt to reconstruct the layout and form of Dwór II [Manor house II] in Strzyża Górna and to present its owner. The manor house was one of several manor houses situated in the upper part of the Strzyża Górna stream. On 17 September 1761 a wealthy merchant from Gdansk Frantz Gottfried Rottenburg became its owner. He was a Catholic associated with the affluent families of other Catholics from Gdansk via family and social connections. The families he was connected with were: the Brunattis (his wife came from this family), the de Matthys, the Metzells and the Schultzs. Some time after he had purchased the manor house in Strzyża Górna, the house was totally reconstructed and rebuilt. Both the house and the garden were planned according to the fashion of the period. The advantages of its location were taken to the full. At the back of the house there was a garden in the form of a terrace, admired by numerous visitors. It was at this side of the house that all the representative rooms of the manor house, guest-rooms, and the orangery were located. From the upstairs it was possible to enjoy a view at the meadows and the sea. 